\title{
Clinical Characteristics and Outcomes of Hyphema in Patients with Sickle Cell Trait: I0-Year Experience at the Wilmer Eye Institute
}

This article was published in the following Dove Press journal: Clinical Ophthalmology

\author{
Tahreem Mir' \\ Mustafa Iftikhar ${ }^{2}{ }^{2}$ \\ Natalie Seidel ${ }^{2}$ \\ Michelle Trang (iD) ${ }^{2}$ \\ Morton F Goldberg ${ }^{2}$ \\ Fasika A Woreta iD $^{2}$ \\ 'Department of Ophthalmology \& Visual \\ Science, Yale School of Medicine, New \\ Haven, CT, USA; ${ }^{2}$ Wilmer Eye Institute, \\ Johns Hopkins University School of \\ Medicine, Baltimore, MD, USA
}

Correspondence: Fasika A Woreta Wilmer Eye Institute, Johns Hopkins University School of Medicine, 600 North Wolfe Street, Wilmer B29, Baltimore, MD 21287 , USA

Tel + I 4I0-955-5650

Fax + | 4I0-6I4-8496

Email fworetal@jhmi.edu
Purpose: To report the clinical characteristics, complications, and outcomes of hyphema in patients with sickle cell trait (SCT).

Design: Retrospective case series.

Methods: Medical records of SCT patients (confirmed by hemoglobin electrophoresis) presenting with hyphema at the Wilmer Eye Institute over 10 years (January 2008 through December 2017) were reviewed in detail. Data were collected regarding etiology, demographics, clinical course and management. Main outcome measures included intraocular pressure (IOP) and visual acuity (VA).

Results: A total of 14 black patients (males: 57\%; median age: 20 years) were included in the study with a median follow-up of 4 months (range: 1 week to 6 years). Ten patients had traumatic hyphema with a mean presenting VA of approximately $1.10 \operatorname{logMAR}$ (Snellen equivalent $=20 / 250$ ) and a mean presenting IOP of $40 \mathrm{mmHg}$. Nine of them required medical intervention to lower IOP, and six of them ultimately required surgical intervention, primarily in the form of anterior chamber paracentesis and/or washout. The mean time to achieve IOP control was 3 days, and the mean final VA was approximately $0.10 \operatorname{logMAR}$ (Snellen Equivalent=20/25). Four patients had non-traumatic hyphema with a mean presenting VA of approximately $1.8 \log$ MAR (Snellen equivalent=20/1260) and a mean presenting IOP of $31 \mathrm{mmHg}$. Three of them required medical intervention to lower IOP, and two of them ultimately required surgical intervention. Overall, seven patients underwent anterior chamber washout, six needed an anterior chamber paracentesis to lower the IOP, two required tube shunt placement procedures and one patient underwent a trabeculectomy. The mean time to achieve IOP control was 5 days, and the mean final VA was approximately $0.80 \log$ MAR (Snellen equivalent $=20 / 125$ ).

Conclusion: Patients with SCT are likely to develop elevated IOP in the setting of hyphema, with a majority requiring one or more surgical interventions to achieve IOP control.

Keywords: hyphema, sickle cell trait, elevated intraocular pressure

\section{Introduction}

Hyphema is a relatively common consequence of blunt ocular trauma but can be challenging to manage. ${ }^{1,2}$ This is especially true for patients with sickle cell hemoglobinopathy, as they are known to have an increased risk of developing hyphema-related complications compared to the non-sickling population. ${ }^{3,4}$ Intraocular pressure (IOP) elevation is one of the most common of these complications. 
Patients with sickle cell hemoglobinopathy can develop severe elevations in IOP despite relatively small amounts of blood in the anterior chamber. ${ }^{5}$ This is because erythrocytes with hemoglobin $\mathrm{S}$ (even from patients with the relatively benign genotype of sickle cell trait) are likely to sickle in aqueous humor and cause mechanical obstruction within the trabecular meshwork. ${ }^{6-9}$ The elevated IOP can, in turn, lead to sight-threatening complications such as corneal blood staining and glaucomatous optic neuropathy. ${ }^{10}$ Therefore, early control of IOP remains a cornerstone in the management of hyphema in sickle cell hemoglobinopathy.

Unfortunately, there are no randomized controlled trials to provide definitive data regarding treatment strategies. Current clinical evidence is limited to retrospective studies published decades ago. ${ }^{11,12}$ As such, ophthalmologists have to rely heavily on their clinical judgment when managing these patients.

In this study, we describe our experience of managing hyphema patients with sickle cell trait at the Wilmer Eye Institute over a recent decade. Given the lack of any definitive clinical trials or large multicenter studies, we aim to provide updated information regarding the clinical course, complications, and management of such patients.

\section{Methods}

A retrospective chart review was conducted for patients with hyphema and sickle cell trait presenting to the Wilmer Eye Institute, Johns Hopkins Hospital, Baltimore from January 2008 through December 2017. Patients were initially identified using ICD-9 codes for hyphema, and individual records were reviewed to select those with sickle cell hemoglobinopathy (initially screened using the sickle cell rapid test with subsequent confirmation by hemoglobin electrophoresis). The study was approved by the Johns Hopkins School of Medicine Institutional Review Board and adhered to all tenets of the Declaration of Helsinki. A waiver of informed consent was obtained and individual patient consent was not required by the IRB. The retrospective nature of our study made it difficult to obtain informed consent from individual patients. Patient data confidentiality was ensured by limiting access to patient charts to only study team members directly involved in data collection. All data were password protected and deidentified prior to analysis.

A total of 17 consecutive patient records met inclusion criteria, out of which 2 were excluded because the patients were lost to follow-up immediately after presentation, and 1 was excluded because the patient presented 3 weeks after the initial injury. The remaining 14 records represented patients examined within hours of symptomatic onset. Data were collected regarding demographics (age, sex, race, medical and ocular history), baseline features (etiology, visual acuity, intraocular pressure, slit-lamp, and fundus examination findings) and longitudinal follow-up (complications, management, and outcomes). Follow-up data were available for a median duration of 4 months (range: 2 weeks to 6 years).

Hyphema size was graded according to previously established criteria: ${ }^{13}$

- Grade 0: dispersed red blood cells with no visible layering (microhyphema)

- Grade 1: layered blood occupying less than one-third of the anterior chamber

- Grade 2: layered blood occupying one-third to less than half of the anterior chamber

- Grade 3: layered blood occupying half to less than the total of the anterior chamber

- Grade 4: total filling of the anterior chamber with blood or blood clot (8-ball hyphema)

Visual acuity (with current correction) was measured using the Snellen chart and converted to the logarithm of the Minimum Angle of Resolution (logMAR) scale for analysis. IOP elevation was defined as an average IOP $>22 \mathrm{mmHg}$, whereas IOP control was defined as an average IOP $\leq 22 \mathrm{mmHg}$ with no spikes above $30 \mathrm{mmHg}$. As all study data were collected retrospectively, management strategies varied across providers and there was no standardized treatment protocol.

Summary statistics are presented as either mean $( \pm$ standard error) or median (with range), depending on the variable's distribution. Stata version 14 (StataCorp) was used for all statistical analyses.

\section{Results}

All 14 patients were black and had sickle cell trait (hemoglobin AS), not sickle cell disease (hemoglobin SS, SC or Sthal). Of the 14, 10 had traumatic hyphema, whereas 4 had non-traumatic hyphema. Table 1 describes the baseline characteristics and outcome measures for each patient.

\section{Traumatic Hyphema}

The most common causes of traumatic hyphema were sports and recreational activities $(60 \%)$ followed by assault (30\%). Concurrent ocular injuries included orbital fracture $(n=1)$, corneal abrasion $(n=2)$, iris sphincter tear 
Table I Baseline Characteristics and Main Outcome Measures of Hyphema Patients with Sickle Cell Trait

\begin{tabular}{|c|c|c|c|c|c|c|c|c|c|c|}
\hline $\begin{array}{l}\text { Patient } \\
\text { ID }\end{array}$ & Age & Sex & Etiology & $\begin{array}{l}\text { Hyphema } \\
\text { Grade I }\end{array}$ & $\begin{array}{l}\text { Presenting } \\
\text { VA, LogMAR } \\
\text { (Snellen } \\
\text { Equivalent) }\end{array}$ & $\begin{array}{l}\text { Presenting } \\
\text { IOP, } \\
\mathrm{mmHg}\end{array}$ & $\begin{array}{l}\text { Last } \\
\text { Visit*, } \\
\text { Days }\end{array}$ & $\begin{array}{l}\text { Final } \\
\text { VA, } \\
\text { LogMAR }\end{array}$ & $\begin{array}{l}\text { Final } \\
\text { IOP, } \\
\text { mmHg }\end{array}$ & Complications \\
\hline \multicolumn{11}{|c|}{ Traumatic Hyphema } \\
\hline 1 & 22 & $M$ & Assault & 4 & $2.8(20 / 12,619)$ & 39 & 1109 & 0.1 & 9 & $\begin{array}{l}\text { Traumatic } \\
\text { cataract }\end{array}$ \\
\hline 2 & 45 & M & Bungee cord & I & $1.0(20 / 200)$ & 59 & 415 & 0.4 & 16 & $\begin{array}{l}\text { Vitreous } \\
\text { prolapse }\end{array}$ \\
\hline 3 & 35 & $M$ & Assault & 1 & $0.5(20 / 63)$ & 12 & 354 & 0.2 & 17 & Rebleeding \\
\hline 4 & 13 & M & Paintball & 1 & $0.3(20 / 40)$ & 37 & 7 & 0.0 & 22 & \\
\hline 5 & 15 & $M$ & Football & I & $2.3(20 / 3990)$ & 45 & 12 & 0.0 & 11 & Angle recession \\
\hline 6 & II & $M$ & Boomerang & 4 & $1.2(20 / 3 \mid 7)$ & 60 & 168 & 0.0 & 14 & \\
\hline 7 & 12 & $M$ & Football & 0 & $0.1(20 / 25)$ & 45 & 16 & 0.0 & 12 & \\
\hline 8 & 12 & $\mathrm{~F}$ & Ball & I & $2.3(20 / 3990)$ & 42 & 1496 & 0.1 & 13 & \\
\hline 9 & 5 & $\mathrm{~F}$ & $\begin{array}{l}\text { Unspecified } \\
\text { object }\end{array}$ & I & $0.5(20 / 63)$ & 42 & 19 & 0.2 & 14 & \\
\hline 10 & 18 & $M$ & Assault & 0 & $0.2(20 / 32)$ & 17 & 7 & 0.2 & 15 & \\
\hline \multicolumn{11}{|c|}{ Non-traumatic Hyphema } \\
\hline II & 67 & $\mathrm{~F}$ & $\begin{array}{l}\mathrm{NVI} \\
\text { secondary } \\
\text { to PDR }\end{array}$ & 1 & $2.3(20 / 3990)$ & 13 & 91 & 0.3 & 15 & \\
\hline 12 & 73 & $\mathrm{~F}$ & $\begin{array}{l}\text { NVI } \\
\text { secondary } \\
\text { to CRVO }\end{array}$ & I & $2.3(20 / 3990)$ & 53 & 875 & $0.7^{2}$ & $20^{2}$ & \\
\hline 13 & 54 & $\mathrm{~F}$ & Spontaneous & I & $0.6(20 / 80)$ & 40 & 14 & 0.2 & 10 & \\
\hline 14 & 68 & $\mathrm{~F}$ & $\begin{array}{l}\mathrm{NVI} \\
\text { secondary } \\
\text { to PDR }\end{array}$ & 0 & $2.0(20 / 2000)$ & 16 & 2276 & $2.0^{3}$ & $8^{3}$ & \\
\hline
\end{tabular}

Notes: 'As per classification by Edwards and Layden; $1973^{13} .{ }^{2}$ At year 2 (before subsequent worsening of underlying neovascular glaucoma). ${ }^{3}$ Before enucleation (performed for blind painful eye). *Days between presentation and last clinic visit.

Abbreviations: CRVO, central retinal vein occlusion; IOP, intraocular pressure; LogMAR, log of the minimum angle of resolution; NVI, neovascularization of the iris; PDR, proliferative diabetic retinopathy; VA, visual acuity.

$(n=1)$, vitreous hemorrhage $(n=3)$ and commotio retinae $(\mathrm{n}=4)$. There were no open globe injuries.

The majority of traumatic hyphema patients were male $(80 \%)$ with a mean age of $19 \pm 4$ years. One patient had systemic hypertension, and one had diabetes mellitus. No patient had pre-existing glaucoma or bleeding disorder, and no patient was on any antiplatelet/anticoagulant medications.

Most patients with traumatic hyphema had a grade 1 hyphema (60\%). The mean presenting VA was $1.1 \pm 0.3$ $\log$ MAR (Snellen equivalent $=20 / 250$ ), and the mean presenting IOP was $40 \pm 5 \mathrm{mmHg}$ (range: $12-60 \mathrm{mmHg}$ ).

IOP elevation was the most frequently observed complication in these patients, occurring in 9 out of 10. Eight patients were diagnosed with IOP elevation on day 1 (at presentation). One patient rebled on days 2 and 6 , and subsequently developed IOP elevation on day 6 (IOP $>40 \mathrm{mmHg}$ ). Figure 1 and Table 2 describe the timing, course, and management of IOP elevation for each traumatic hyphema patient in detail. 

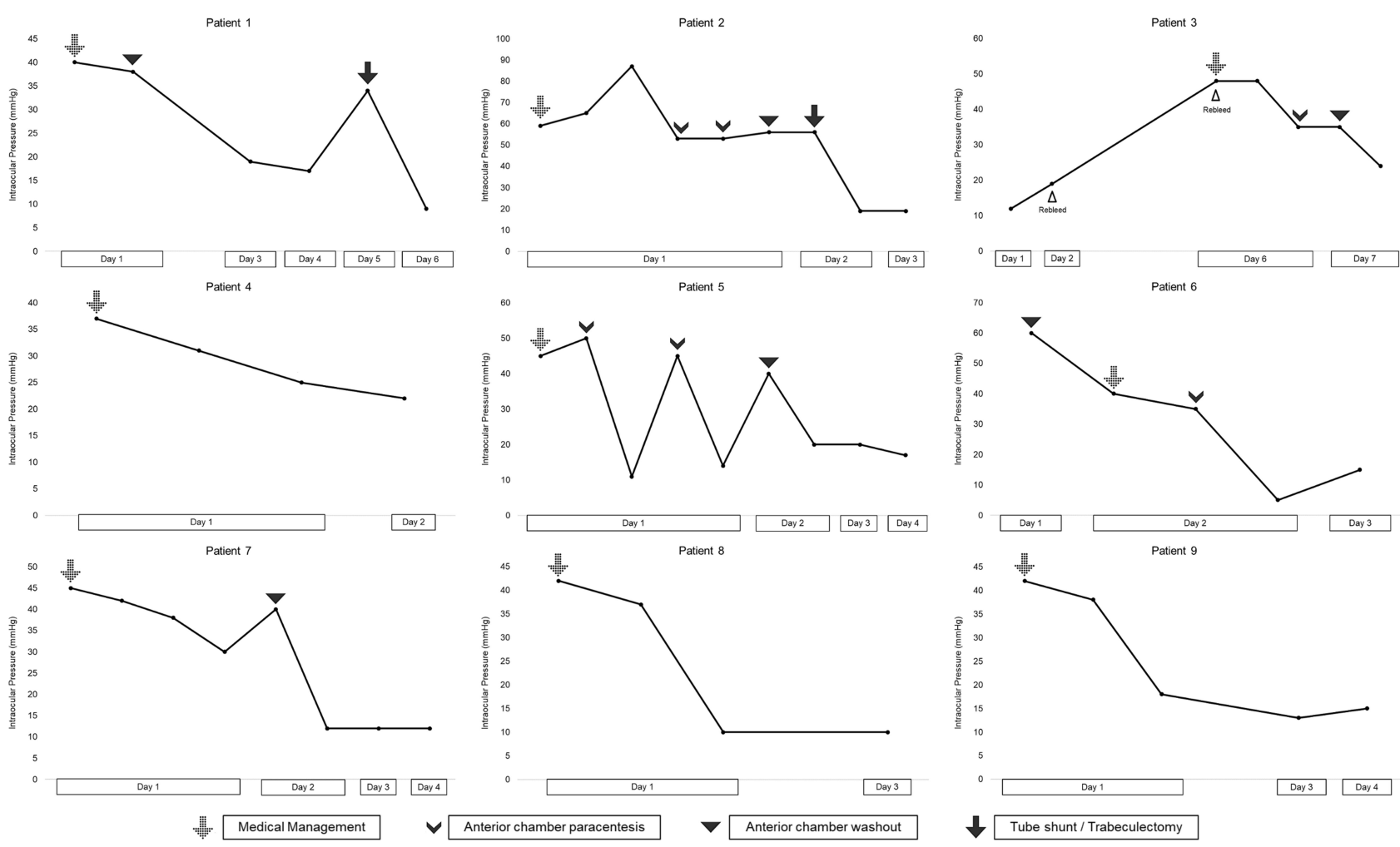

Figure I Clinical course and management of elevated IOP in traumatic hyphema patients with sickle cell trait. Average IOP is plotted against time. Markers indicate an intervention performed to achieve IOP control. Medical management, once initiated, was continued until normalization of IOP.

Other complications included angle recession $(\mathrm{n}=1$, diagnosed at presentation and lost to follow-up after resolution of hyphema), traumatic cataract $(\mathrm{n}=1$, diagnosed at year 2 with cataract extraction performed at year 3 ), and vitreous prolapse $(\mathrm{n}=1$, noted during anterior chamber washout, pars plana vitrectomy and lensectomy performed to prevent clogging of a tube shunt). A complete list of complications is included in Table 1. There were no cases of corneal blood staining, peripheral anterior synechiae, pupillary block or glaucomatous optic neuropathy.

In addition to standard hyphema precautions (eye shield, limited activity, head elevation), almost all traumatic hyphema patients $(90 \%)$ received supportive care (topical cycloplegics and corticosteroids). Patients with IOP elevation were initially managed with topical agents including beta-blockers $(\mathrm{n}=9)$, alpha agonists $(\mathrm{n}=8)$, prostaglandin analogs $(\mathrm{n}=8)$, and carbonic anhydrase inhibitors $(n=4)$. In select cases, oral acetazolamide $(n=1)$ and intravenous mannitol $(n=2)$ were also utilized. However, two-thirds of traumatic hyphema patients with IOP elevation were refractory to medical therapy and required surgical intervention in the form of anterior chamber paracentesis $(n=3)$, anterior chamber washout $(n=6)$, tube shunt surgery $(n=1)$ or trabeculectomy $(n=1)$.
The mean number of surgical interventions per patient was $1.4 \pm 0.5$, and the median time from presentation to first surgical intervention was 1 day (range: 1-6 days). Table 3 describes the indication and timing of surgical intervention for each patient.

The median length of follow-up was 3 months (range: 1 week to 4 years). The mean time to resolution of hyphema was $6 \pm 2$ days. The mean time to achieve IOP control was $3 \pm 1$ days, and the mean IOP at the last follow-up was $14 \pm 1 \mathrm{mmHg}$. The mean VA at the last follow-up was $0.1 \pm 0.04 \log$ MAR (Snellen equivalent= 20/25).

\section{Non-Traumatic Hyphema}

The most commonly identified cause of non-traumatic hyphema was neovascularization of the iris (75\%) secondary to diabetic retinopathy $(\mathrm{n}=2)$ or retinal vein occlusion $(\mathrm{n}=1)$. One patient had spontaneous hyphema without any identifiable cause. All of these patients were hypertensive females with a mean age of $66 \pm 4$ years. Three had diabetes mellitus, two had neovascular glaucoma, and one had primary open-angle glaucoma. No patient had any bleeding disorder, and none was on any antiplatelet/ anticoagulant medications. 


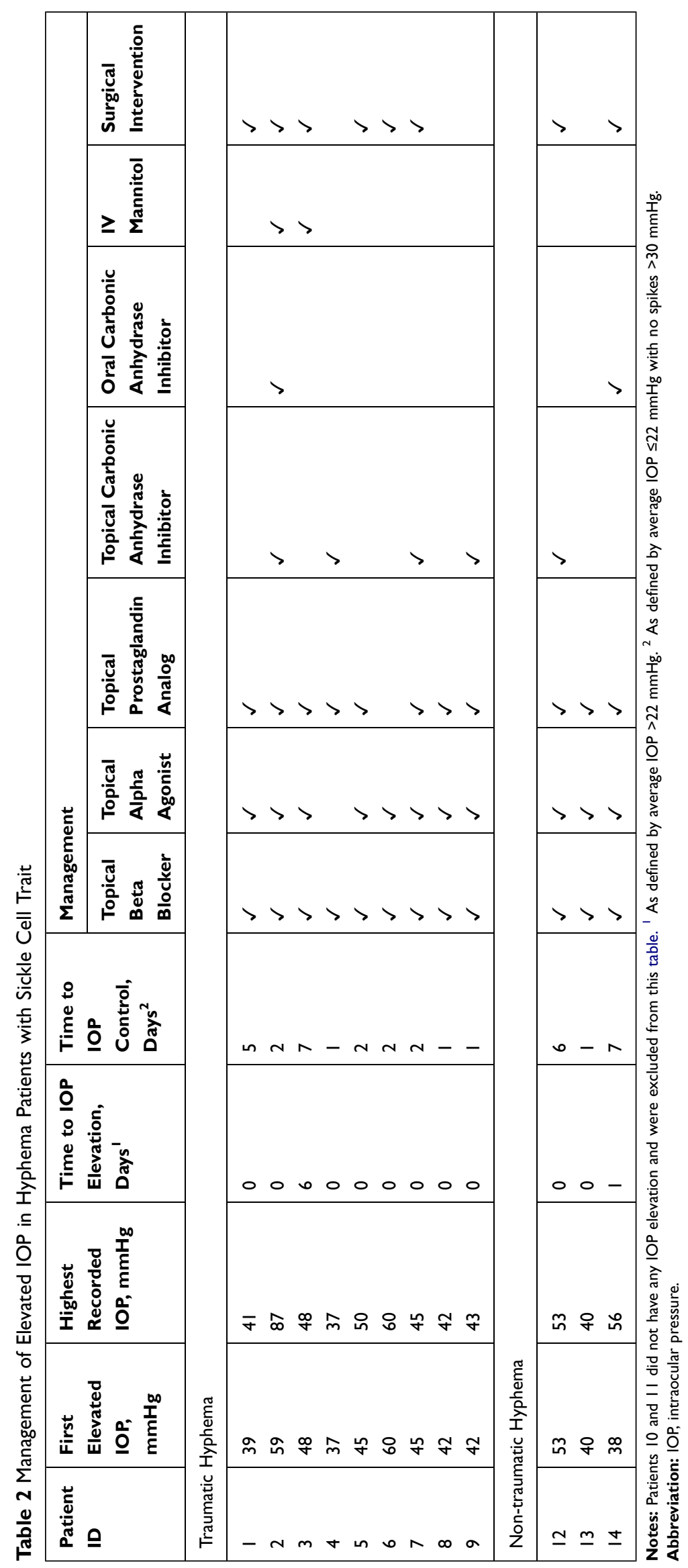


Table 3 Surgical Intervention in Hyphema Patients with Sickle Cell Trait

\begin{tabular}{|c|c|c|c|}
\hline Patient ID & Indication & Day & Intervention \\
\hline I & $\begin{array}{l}\text { IOP persistently }>40 \mathrm{mmHg} \text { after } \mathrm{MMT} \\
\text { IOP persistently }>30 \mathrm{mmHg} \text { after anterior chamber washout and MMT }\end{array}$ & $\begin{array}{l}1 \\
5\end{array}$ & $\begin{array}{l}\text { Anterior chamber washout } \\
\text { Trabeculectomy }\end{array}$ \\
\hline 2 & $\begin{array}{l}\text { IOP persistently }>50 \mathrm{mmHg} \text { after MMT (including PO Diamox and IV mannitol) } \\
\text { IOP persistently }>50 \mathrm{mmHg} \text { after first anterior chamber paracentesis } \\
\text { IOP persistently }>40 \mathrm{mmHg} \text { after second anterior chamber paracentesis } \\
\text { IOP persistently }>50 \mathrm{mmHg} \text { after anterior chamber washout }\end{array}$ & $\begin{array}{l}1 \\
1 \\
1 \\
2\end{array}$ & $\begin{array}{l}\text { Anterior chamber paracentesis } \\
\text { Anterior chamber paracentesis } \\
\text { Anterior chamber washout } \\
\text { Tube shunt surgery }\end{array}$ \\
\hline 3 & $\begin{array}{l}\text { IOP persistently }>30 \mathrm{mmHg} \text { after MMT (including IV mannitol) } \\
\text { IOP persistently }>30 \mathrm{mmHg} \text { after anterior chamber paracentesis }\end{array}$ & $\begin{array}{l}6 \\
7\end{array}$ & $\begin{array}{l}\text { Anterior chamber paracentesis } \\
\text { Anterior chamber washout }\end{array}$ \\
\hline 5 & $\begin{array}{l}\text { IOP persistently }>40 \mathrm{mmHg} \text { after MMT } \\
\text { IOP persistently }>40 \mathrm{mmHg} \text { after first anterior chamber paracentesis } \\
\text { IOP persistently }>40 \mathrm{mmHg} \text { after second anterior chamber paracentesis }\end{array}$ & $\begin{array}{l}1 \\
1 \\
2\end{array}$ & $\begin{array}{l}\text { Anterior chamber paracentesis } \\
\text { Anterior chamber paracentesis } \\
\text { Anterior chamber washout }\end{array}$ \\
\hline 6 & $\begin{array}{l}\text { IOP }>60 \mathrm{mmHg} \text { with Grade } 4 \text { hyphema } \\
\text { IOP persistently }>30 \mathrm{mmHg} \text { after anterior chamber washout and MMT }\end{array}$ & $\begin{array}{l}1 \\
2\end{array}$ & $\begin{array}{l}\text { Anterior chamber washout } \\
\text { Anterior chamber paracentesis }\end{array}$ \\
\hline 7 & IOP persistently $>30 \mathrm{~mm} \mathrm{Hg}$ after MMT & 2 & Anterior chamber washout \\
\hline 12 & $\begin{array}{l}\text { IOP persistently }>40 \mathrm{mmHg} \text { after MMT } \\
\text { IOP persistently }>40 \mathrm{mmHg} \text { after anterior chamber paracentesis } \\
\text { IOP persistently }>40 \mathrm{mmHg} \text { after anterior chamber washout and MMT }\end{array}$ & $\begin{array}{l}1 \\
2 \\
6\end{array}$ & $\begin{array}{l}\text { Anterior chamber paracentesis } \\
\text { Anterior chamber washout } \\
\text { Tube shunt surgery }\end{array}$ \\
\hline 14 & IOP >30 mm Hg with prior neovascular glaucoma & 2 & Anterior chamber paracentesis \\
\hline
\end{tabular}

Abbreviations: IOP, intraocular pressure; MMT, maximum medical therapy (including systemic agents if specified).

Most patients with non-traumatic hyphema had a grade 1 hyphema (75\%). The mean presenting VA was $1.8 \pm 0.4$ $\log$ MAR (Snellen equivalent $=20 / 1260$ ), and the mean presenting IOP was $31 \pm 10 \mathrm{mmHg}$ (range: $13-53 \mathrm{mmHg}$ ).

IOP elevation was the most frequently observed complication in these patients, occurring in three out of four (two on day 1 and one on day 2). Figure 2 and Tables 1 and 2 describe the timing, course, and management of IOP elevation for each non-traumatic hyphema patient in detail. There were no cases of rebleeding, corneal blood staining, peripheral anterior synechiae, pupillary block or glaucomatous optic neuropathy.

All of these patients received standard hyphema precautions and supportive care. Those with IOP elevation were initially managed with topical agents, including betablockers $(n=3)$, alpha agonists $(n=3)$, prostaglandin ana$\operatorname{logs}(\mathrm{n}=3)$, and carbonic-anhydrase inhibitors $(\mathrm{n}=1)$ as specified in Table 2. Oral acetazolamide was also used in 1 case. However, two required surgical intervention in the form of anterior chamber paracentesis $(\mathrm{n}=2)$, anterior chamber washout $(n=1)$, and tube shunt surgery $(n=1)$. For patient 14, further surgical intervention was deferred after day 3 due to patient preference and poor baseline vision.
The median length of follow-up was 15 months (range: 2 weeks to 6 years). The mean time to resolution of hyphema was $16 \pm 9$ days. The mean time to achieve IOP control was $5 \pm 2$ days, and the mean IOP at the last follow-up was $13 \pm 5 \mathrm{mmHg}$. Four patients continued to be on topical IOP lowering drops at the time of the final follow-up visit. The mean VA at the last follow-up was 0.8 $\pm 0.4 \log$ MAR (Snellen equivalent=20/125).

\section{Discussion}

The high incidence and rapid onset of IOP elevation observed in this study, combined with the high rate of surgical interventions performed for IOP control, highlight the importance of IOP management for patients with hyphema and sickle cell trait.

In the largest case series of hyphema patients with sickle cell trait (22 eyes), Deutsch et al reported the need for surgical intervention in $36 \%$ of the patients. ${ }^{11} \mathrm{We}$ report a much higher rate of $57 \%$. It is possible that the increased rate is reflective of a lower threshold for intervention employed by ophthalmologists in recent years. Indeed, it is now known that for patients with sickle cell trait, the size of hyphema does not correlate with the extent of IOP elevation and that even modest elevations 

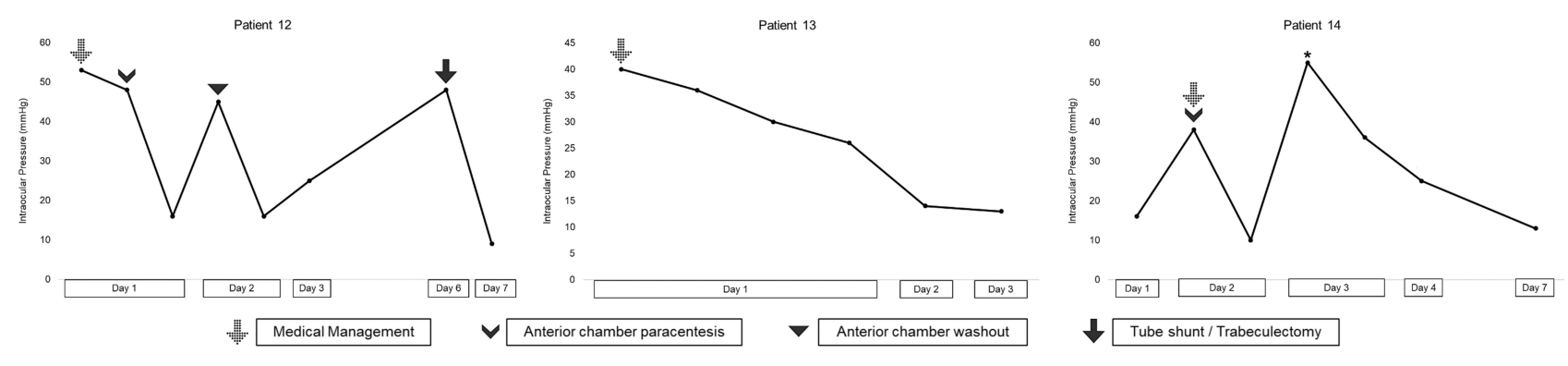

Figure 2 Clinical course and management of elevated IOP in non-traumatic hyphema patients with sickle cell trait. Average IOP is plotted against time. Markers indicate an intervention performed to achieve IOP control. Medical management, once initiated, was continued until normalization of IOP. For patient I4, further surgical management was deferred after day $3\left(^{*}\right)$ due to patient preference and poor baseline vision.

can trigger further complications such as glaucomatous optic neuropathy or retinal vascular occlusion. ${ }^{1,14-17}$ Such data may have led to ophthalmologists favoring a more aggressive approach when managing sickle cell trait patients more recently. Nonetheless, there is still considerable controversy regarding such an approach. ${ }^{18}$

Traditionally, for patients with hyphema and sickle cell hemoglobinopathy, surgical intervention has been recommended if the IOP averages $>24 \mathrm{mmHg}$ over 24 hours, or if it repeatedly increases above $30 \mathrm{mmHg} .{ }^{11}$ In general, the evidence behind this recommendation is limited. However, while we cannot make any definitive conclusions based on our recent data, it is important to note that none of our patients developed any major IOP related complication (such as glaucomatous optic neuropathy, corneal bloodstaining, or retinal vascular occlusion) or any iatrogenic postoperative complication (such as rebleeding or lens injury). Therefore, the benefits of early IOP control may outweigh potential risks, and the "24 for 24 rule" remains a useful guide for management.

Although anterior chamber paracentesis and/or washout was sufficient in achieving IOP control for most patients, three patients did require further surgical intervention in the form of tube shunt surgery or trabeculectomy. Kaplowitz et al recommended considering trabeculectomy in patients with traumatic hyphema and sickle cell hemoglobinopathy. ${ }^{19}$ However, the evidence supporting the argument is weak, and the potential benefits of the procedure must be weighed carefully against its risks.

Of note, prior studies have cautioned against the repetitive or continuing use of hyperosmolar agents (such as mannitol) or systemic carbonic anhydrase inhibitors (such as acetazolamide) as they can cause hemoconcentration and increased blood viscosity in the ocular microvasculature, leading to erythrocyte sickling. ${ }^{5,15}$ Systemic carbonic anhydrase inhibitors also carry the theoretical risk of exacerbating erythrocyte sickling via metabolic changes. ${ }^{20}$ In this study, one patient received oral acetazolamide, one patient received intravenous mannitol, and one patient received both. None of the agents caused any systemic side effects. At the same time, none of the agents was able to sufficiently control IOP and avoid surgical intervention (for patient 14, further surgical intervention was deferred due to patient preference). As such, it is difficult to determine whether these agents played any role in worsening IOP themselves or whether their failure was a function of disease severity. Given the small sample size and limited data, it is difficult to make any conclusions regarding their safety and efficacy, and the decision to use them should be individualized for each patient.

Rebleeding is usually considered to be the worst prognostic factor for hyphema, because it predisposes patients to further complications. ${ }^{21,22}$ Although certain studies claim that sickle cell hemoglobinopathy confers an increased risk of rebleeding in hyphema, the evidence remains conflicting. ${ }^{3,4,23}$ In this study, there was only one case of rebleeding, and that patient did develop elevated IOP.

The primary limitations of this study are its retrospective single-center design and small sample size. Furthermore, as the Wilmer Eye Institute is a tertiary care facility, the study may be subject to referral bias, and the patients may not be reflective of the general sickling population. In patients with hyphema in the setting of iris neovascularization, gonioscopy was often not possible due to poor view to the angle and hence it could not be accurately determined if the IOP elevation was the result of hyphema or angle neovascularization.

In conclusion, black patients with hyphema should be routinely screened for sickle cell hemoglobinopathy (including sickle cell trait) because it warrants a closer follow-up for IOP assessment and a lower threshold for surgical intervention. Screening should also be considered in patients of 
Mediterranean and Indian descend. Given the absence of any standardized guidelines and the dearth of prospective data, further studies are needed to determine the optimal timing and indications of such interventions.

\section{Disclosure}

The authors report no conflicts of interest for this work.

\section{References}

1. Walton W, Von Hagen S, Grigorian R, Zarbin M. Management of traumatic hyphema. Surv Ophthalmol. 2002;47(4):297-334. doi:10.1016/S0039-6257(02)00317-X

2. Bansal S, Gunasekeran DV, Ang B, et al. Controversies in the pathophysiology and management of hyphema. Surv Ophthalmol. 2016;61(3):297-308. doi:10.1016/j.survophthal.2015.11.005

3. Nasrullah A, Kerr NC. Sickle cell trait as a risk factor for secondary hemorrhage in children with traumatic hyphema. Am J Ophthalmol. 1997;123(6):783-790. doi:10.1016/S0002-9394(14)71127-4

4. Lai JC, Fekrat S, Barron Y, Goldberg MF. Traumatic hyphema in children: risk factors for complications. Arch Ophthalmol. 2001;119(1):64-70.

5. Goldberg MF. Sickled erythrocytes, hyphema, and secondary glaucoma. I. The diagnosis and treatment of sickled erythrocytes in human hyphemas. Ophthalmic Surg. 1979;10(4):17-31.

6. Goldberg MF, Dizon R, Raichand M. Sickled erythrocytes, hyphema, and secondary glaucoma. II. Injected sickle cell erythrocytes into human, monkey, and guinea pig anterior chambers. The induction of sickling and secondary glaucoma. Ophthalmic Surg. 1979;10(4):32-51.

7. Goldberg MF, Dizon R, Raichand M, Goldbaum M, Jampol LM. Sickled erythrocytes, hyphema, and secondary glaucoma. III. Effects of sickle cell and normal human blood samples in rabbit anterior chambers. Ophthalmic Surg. 1979;10(4):52-61.

8. Goldberg MF. Sickled erythrocytes, hyphema, and secondary glaucoma. IV. The rate and percentage of sickling of erythrocytes in rabbit aqueous humor, in vitro and in vivo. Ophthalmic Surg. 1979;10(4):62-69.

9. Goldberg MF, Tso MOM. Sickled erythrocytes, hyphema, and secondary glaucoma. VII. The passage of sickled erythrocytes out of the anterior chamber of the human and monkey eye. Light and electron microscopic studies. Ophthalmic Surg. 1979;10(4):89-123.

10. Crouch ER. Traumatic Hyphema. J Pediatr Ophthalmol Strabismus. 1986;23(2):95-97.
11. Deutsch TA, Weinreb RN, Goldberg MF. Indications for surgical management of hyphema in patients with sickle cell trait. Arch Ophthalmol. 1984;102(4):566-569. doi:10.1001/archopht.1984.010 40030444022

12. Friedman AH, Halpern BL, Friedberg DN, Wang FM, Podos SM. Transient open-angle glaucoma associated with sickle cell trait: report of 4 cases. Br J Ophthalmol. 1979;63(12):832-836.

13. Edwards WC, Layden WE. Traumatic hyphema. A report of 184 consecutive cases. Am J Ophthalmol. 1973;75(1):110-116. doi:10. 1016/0002-9394(73)90659-4

14. Crouch ER, Frenkel M. Aminocaproic acid in the treatment of traumatic hyphema. Am J Ophthalmol. 1976;81(3):355-360. doi:10.1016/ 0002-9394(76)90254-3

15. Radius RL, Finkelstein D. Central retinal artery occlusion (reversible in sickle trait with glaucoma. Br J Ophthalmol. 1976;60(6):428-430. doi:10.1136/bjo.60.6.428

16. Wax MB, Ridley ME, Magargal LE. Reversed of retinal and optic disc ischemia in a patient with sickle cell trait and glaucoma secondary to traumatic hyphema. Ophthalmology. 1982;89(7):845-851. doi:10.1016/S0161-6420(82)34715-6

17. Patel AK, Downey L, Dabbs TR. Traumatic and postoperative hyphaema in a patient with sickle cell trait [13]. Eye. 2004;18 (2):212-214. doi:10.1038/sj.eye.6700591

18. Leffler CT, Bharucha G, Donaldson J. Management of hyphema in patients with sickle cell disease or trait. Surv Ophthalmol. 2016;61 (5):689-690.

19. Kaplowitz K, Nobe M, Abazari A, Honkanen R. Trabeculectomy for traumatic hyphema in sickle cell trait. Semin Ophthalmol. 2015;30 (4):297-304. doi:10.3109/08820538.2013.847108

20. Goldberg MF. Sickled erythrocytes, hyphema, and secondary glaucoma. V. The effect of vitamin C on erythrocyte sickling in aqueous humor. Ophthalmic Surg. 1979;10(4):70-77.

21. Read J, Goldberg MF. Comparison of medical treatment for traumatic hyphema. Trans Am Acad Ophthalmol Otolaryngol. 1974;78 (5):799-815.

22. Gharaibeh A, Savage HI, Scherer RW, Goldberg MF, Lindsley K. Medical interventions for traumatic hyphema. Cochrane Database Syst Rev. 2019;1(1):CD005431.

23. Spoor TC, Kwitko GM, O'Grady JM, Ramocki JM. Traumatic hyphema in an urban population. Am J Ophthalmol. 1990;109 (1):23-27. doi:10.1016/S0002-9394(14)75573-4
Clinical Ophthalmology

\section{Publish your work in this journal}

Clinical Ophthalmology is an international, peer-reviewed journal covering all subspecialties within ophthalmology. Key topics include: Optometry; Visual science; Pharmacology and drug therapy in eye diseases; Basic Sciences; Primary and Secondary eye care; Patient Safety and Quality of Care Improvements. This journal is indexed on PubMed

\section{Dovepress}

Central and CAS, and is the official journal of The Society of Clinical Ophthalmology (SCO). The manuscript management system is completely online and includes a very quick and fair peer-review system, which is all easy to use. Visit http://www.dovepress.com/ testimonials.php to read real quotes from published authors. 